Nagy, Oana - Păcurar, Bogdan

\title{
The Five-Minute-Walk Distance Concept, Case Study: City of Cluj-Napoca, Romania
}

This concept, also known as "pedestrian shed", refers to the distance that would make the difference for a person to choose between walking or driving to a destination. The distance is visualized as a 400-meter radius area that is most frequently located in the downtown areas/key areas of some large cities or capitals. To better underline this concept's characteristics we have applied it on a case study of the city of Cluj-Napoca, testing the conformance of several areas against the concept's principles. This will show the percentage of studied areas complying with the concept requirements and the conclusions will indicate the proposed set of measures to be applied by the local authorities in order to improve the area concept validation score and, with this, to improve the citizens quality of life. This concept could be easily replicated in any city or capital and its metrics could be used to assess citizens' needs and strongly indicate the measures that are required in order to stimulate walking instead of driving, as a direct result of providing all modern required facilities within a 5-minute walking area.

Keywords: neighborhood, 5-minute walking distance, urban development, city driving, pedestrian shed.

JEL code: $O 18$

https://doi.org/10.32976/stratfuz.2020.7

\section{Introduction}

For an extended period of time, Romania alongside other communist countries, experienced slow development of its cities and its economy. After the fall of the socialist regimes, these states and their cities went through a much different, more rapid development, influenced by neighboring countries and especially by the West, as these influences enabled easy access and principles, ideas and opportunities for exchange which would have been impossible before that time.

This paper aims to provide an overview of the development of large cities according to a concept devised in the 1920s, aimed to develop and attract investments in multiple key points in a city as well as to supplement the role of the city center, thus making other areas of the city more welcoming and attractive for businesses, construction, governance and day-to-day living.

Walkability is becoming a keyword in planning today, as new urbanism ideas are spreading throughout the profession. Many communities today are suffering from a growing dependence on automobiles and road traffic is the main mode of transportation, which results in low-density development and sprawling development patterns. According to Abley (2005, page 3), walkability can be defined as "the extent to which the built environment is friendly to the presence of people living, shopping, visiting, enjoying or spending time in an area". Walkability is also dependent on the human behavior of the residents in the neighborhood area.

\section{Research methodology}

This paper is based on a concept developed by planner and sociologist Arthur Clarence Perry in 1920 in New York. (https://www.conservapedia.com/index.php?title=Clarence_Perry).

$\mathrm{He}$ was the first researcher to observe the correlation between distances, heavy traffic and the multitude of people/pedestrians walking more than 5-10 minutes. Perry was influenced by the rising automobile industry in the United States and identified the car as "a new factor in the development of residential neighborhoods". The goal of Perry's research was to investigate the 
scale, spatial arrangement and land use of residential communities and, ultimately, to provide a planning framework for new neighborhoods. Thusly, he could appreciate and think of a concept that proved to be revolutionary - The Neighborhood Unit.

\section{What is this concept? How does it work?}

The unit of measurement is commonplace in the planning profession and is often represented by a radius measuring one quarter of a mile (400 meters). The average walking speed of a human is at approximately 3 miles $\mathrm{km} / \mathrm{h}$, which translates to $1 / 4$ of a mile in five minutes. (https://morphocode.com/the-5-minute-walk/). Most planners represent the walking distance on a proposed plan drawing or an aerial as a circle drawn with the center of the circle on the destination. Nowadays, the concept is called "pedestrian shed".

(https://urbanlands.co/2010/08/23/the-five-minute-walk-more-than-just-a-circle/).

The pedestrian shed is usually placed around a community center or a common destination such as a school or a public plaza, where social and commercial activity is focused. In urban planning, the "5-minute-walk distance" sets a scope for collecting both quantitative and qualitative data on a human scale.

Perry placed the elementary school in the center of the neighborhood and used it to determine the size and structure of the residential community: the school had to be within reach for all residents and set the quarter-of-a-mile walking distance threshold in the unit scheme (Figure 1). Together with local retail shops, public spaces and residential units, the elementary school was one of the four main functions in the neighborhood unit which means around 65 ha in size that provides housing area for a population of 5,000 to 10,000 people. (Sharifi, A. 2013, page 52)

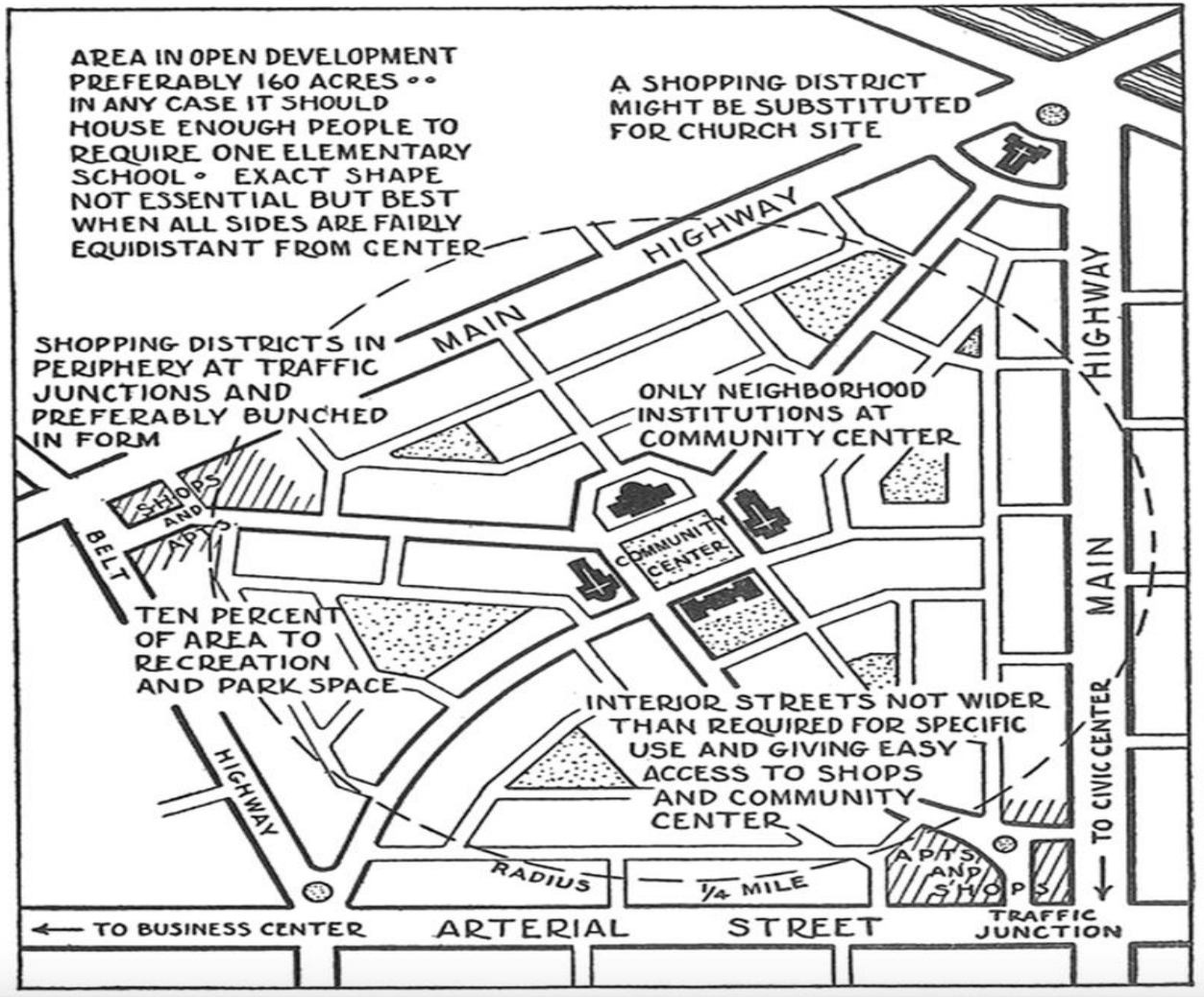

Figure 1: Perry's diagram

Source: https://morphocode.com/the-5-minute-walk/ 
The general assumption that most people are willing to walk for about five minutes before opting to drive has been subject to debate in urban planning. A large part of the research on walking behavior focuses on commuting and access to transit. The duration of walking trips also depends on their purpose. Trips for shopping and reaching transportation are shorter, while recreational walks tend to be longer. Walking behavior depends on a number of location-specific factors such as proximity to destinations and perceived safety. It also varies across age groups and socio-economic status. Both the 5 and 10-minute walk thresholds are applied in planning. (Yong, Y. And Diez-Roux A.V.,2012, page 2)

In regards to this concept, a number of important articles have been written over time without having a materialized impact within a city, being rather parallel studies on a possible variant of regulating and organizing cities like Chicago, Vancouver or Atlanta. From these works, we can point to Chi-Chang Wang's study in a district of Vancouver (Wang, 1965), Banargee and Baer (1984)'s study focusing on residential environments and public policy, and the neighbourhood concept developed by architect Plater-Zyberk (1991) for Atlanta, Georgia.

The general conclusion drawn on the concept developed by Perry is that the concept can be applied in different ways, depending on the vision of the planner and the key point to be reached - the social or the physical one.

\section{Case study - City of Cluj Napoca, Romania}

Most researchers agree that the quarter-of-a-mile $(400 \mathrm{~m})$ radius describing the walkable circle area is a reasonable distance for determining access to public services and as a result for measuring how walkable a community is.

We applied the concept of "5 minutes walk distance" in the City of Cluj-Napoca, focusing on three study areas:

\section{- Bulgaria neighborhood \\ - Gheorgheni neighborhood \\ - Downtown (city center)}

From the necessity to have a well defined study which can display the concept in a more flexible way and which makes the concept easy to understand, I chose a list of three specific neighborhoods, the main points being represented by the facilities and services that are available in that territory. The location of the neighborhoods represents three different categories: the downtown is the central area of the city, where the most numerous and diversified types of services and facilities are located, the Gheorgheni neighborhood, which displays medium characteristics, and the Bulgaria neighborhood, which is the last positioned in terms of services and endowments. With this perfect discrepancy between all three neighborhoods, we considered that the comparison between them will better define the concept developed by Perry.

For calculating the distances from the selected key point (where most of the services and facilities in that neighborhood were concentrated) and destination (the final service/place), we used the Google Earth service and its function of calculating pedestrian distances. Also, to confirm the data provided by Google Earth, we have used the platform www.traveltimeplatform.com, which, like the service provided by Google, allows the calculation of the pedestrian distances from a selected point on a map to a selected destination in a predefined field.

In the study, I considered a series of 14 elements as absolutely necessary to be present in the immediate vicinity of a residential area in order to be chosen as a "typical area" that is, to fit in the concept of the "5-minute-walk distance". I chose as a landmark the central point of the area, where most of the services needed for the population are located. These 14 elements were chosen according to the daily or weekly needs of a citizen: medical services, financial services (banks, insurance, etc), public transportation station, university, schools, kindergarten, 
commercial services (shopping \& retail), park, entertainment services (theatre, cinema), car parking (including underground parking), spare time and meeting points/socializing (restaurants, bar, pedestrian area, coffee shops), beauty services (barber shop, nail salon, hair salon), accommodation services (hotel/guest house), and religious activity (churches).

All of the compared areas are equivalent for the neighborhood they represent. This case study aims to gather on how the neighborhood concept used in urban areas affects the walkability within the neighborhood areas.

a)

Bulgaria Neighborhood

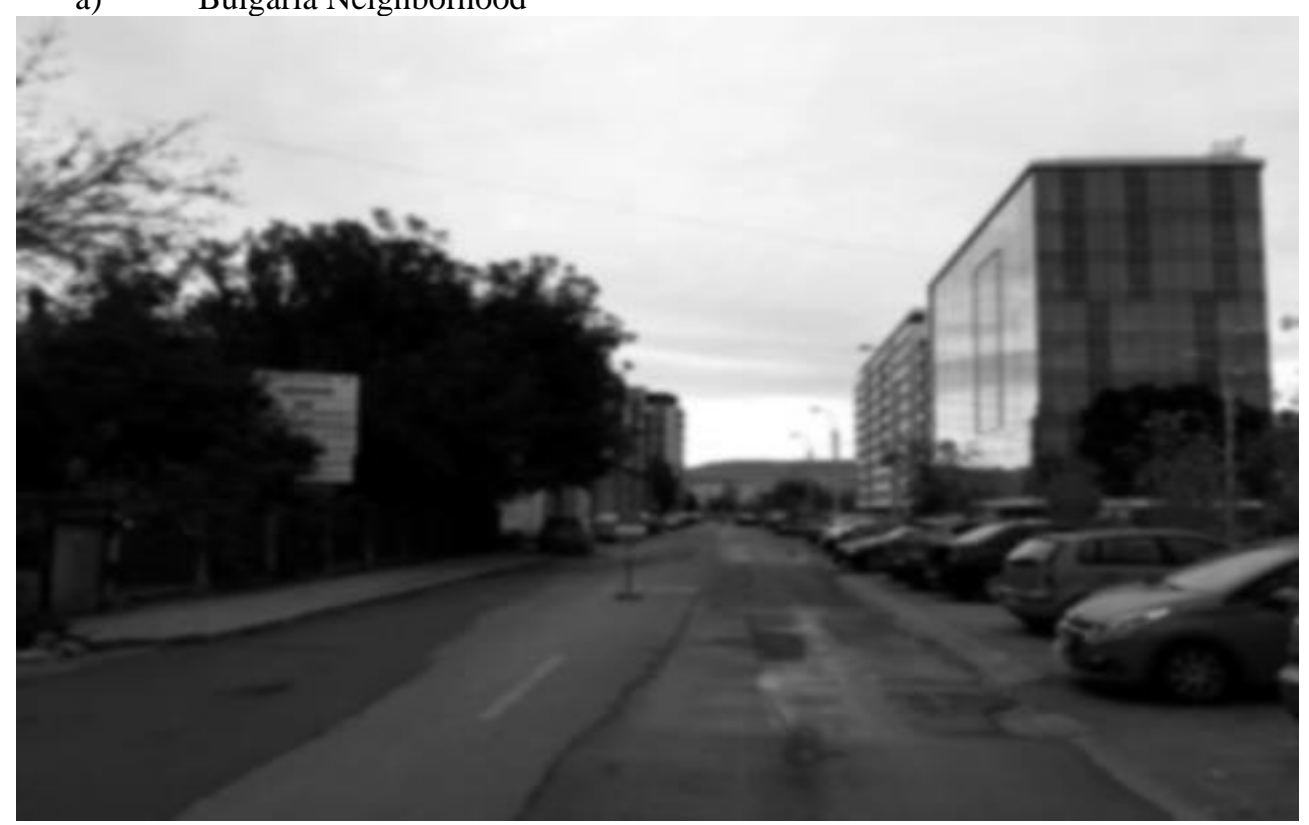

Figure 2:A street in the Bulgaria neighborhood

Source: Own photo

At the origin of the name was a small community of Bulgarian farmers, who arrived in ClujNapoca in the ninth century. Although this community numbered only a few dozen families, the name of the area in which they settled has survived even today. Local historians report that the Bulgarians settled in the eastern part of Cluj-Napoca, fled from the Ottomans and were also good gardeners. Over time, the authenticity of the Bulgarian ethnic group in the area disappeared and formed a neighborhood with predominantly industrial specifics, but which underwent residential changes, housing today about 28,000 inhabitants. Most of the services found in this neighborhood are mostly concentrated in the same place. Although the neighborhood does not easily find several common services such as kindergartens, shops, financial institutions, the area is constantly developing and expanding, with the daily approval of residential and commercial projects and buildings. 
Table 1:

Results of the case study on the Bulgaria neighborhood

\begin{tabular}{|l|l|l|}
\hline & Distance (in minutes) & Distance on foot (in km or m) \\
\hline Medical services & $6 \mathrm{~min}$ & $500 \mathrm{~m}$ \\
\hline Financial services, banks & $15 \mathrm{~min}$ & $1.2 \mathrm{~km}$ \\
\hline Public transport station & $2 \mathrm{~min}$ & $120 \mathrm{~m}$ \\
\hline University & $19 \mathrm{~min}$ & $1.5 \mathrm{~km}$ \\
\hline Schools & $6 \mathrm{~min}$ & $450 \mathrm{~m}$ \\
\hline Kindergarten & $9 \mathrm{~min}$ & $750 \mathrm{~m}$ \\
\hline Shopping center & $15 \mathrm{~min}$ & $1.3 \mathrm{~km}$ \\
\hline Park & $6 \mathrm{~min}$ & $500 \mathrm{~m}$ \\
\hline $\begin{array}{l}\text { Entertainment (cinema, } \\
\text { theatre, opera) }\end{array}$ & $20 \mathrm{~m}$ & $1.7 \mathrm{~km}$ \\
\hline Car parking & $-{ }^{*}$ & - \\
\hline $\begin{array}{l}\text { Free time/ Socializing } \\
\text { (restaurant, bar, coffee shop) }\end{array}$ & $5 \mathrm{~min}$ & $400 \mathrm{~m}$ \\
\hline $\begin{array}{l}\text { Beauty services (barber shop, } \\
\text { hair salon, nails salon) }\end{array}$ & $1 \mathrm{~min}$ & $90 \mathrm{~m}$ \\
\hline $\begin{array}{l}\text { Accommodation services } \\
\text { Hotel/Guest house }\end{array}$ & $4 \mathrm{~min}$ & $350 \mathrm{~m}$ \\
\hline Church & $9 \mathrm{~min}$ & $750 \mathrm{~m}$ \\
\hline
\end{tabular}

Source: Own compilation

*in the area there is no paid parking and monitored by the local administration; cars can be parked in any available space along the street

In the table, results shown in red are beyond the 5-minute distance. The results show that most of the elements in the Bulgaria neighborhood are located at a distance of more than 5 minutes on foot. The inhabitants of this neighborhood have to use a car or public transport instead of walking in order to perform their daily tasks like taking the kids to school or to the playground, shopping, paying bills, using medical services, etc.

b) Gheorgheni Neighborhood

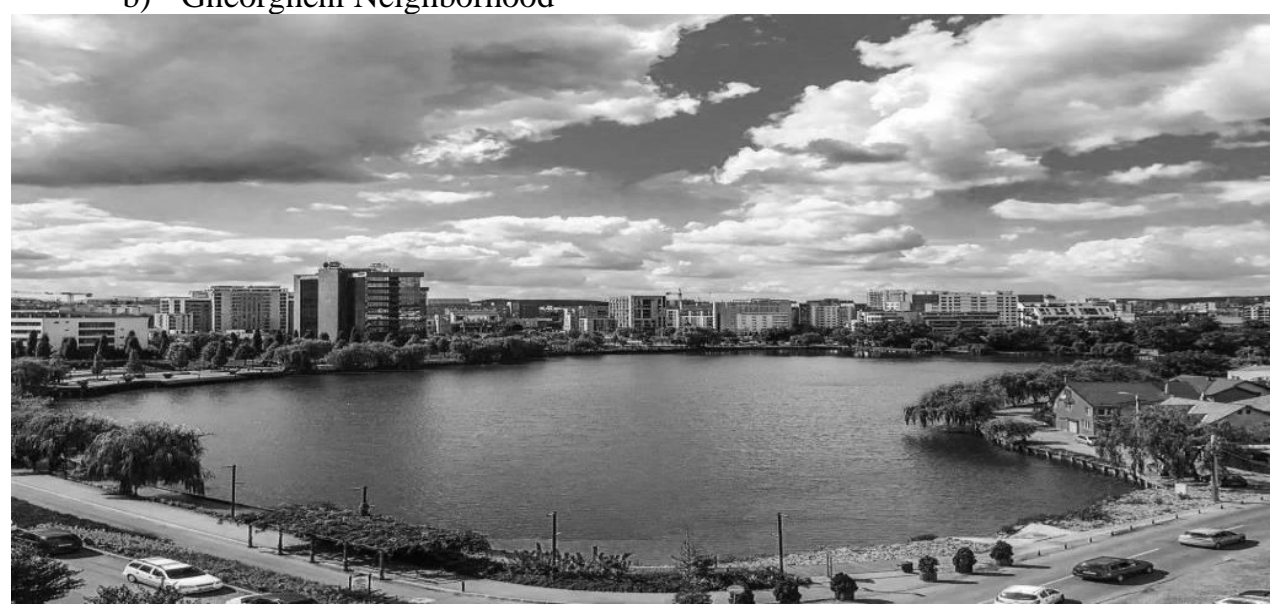

Figure 3: Gheorgheni neighborhood

Source: Own photo 
Gheorgheni neighborhood is the greenest neighborhood and the one that has undergone the smallest changes. The name of the neighborhood comes from the village of Gheorgheni, which is very easy to reach. The neighborhood also includes Gheorgheni Lake, which is almost 600 years old and is also called "Bottomless Lake". The first document dating the existence of the lake is from 1370, and belonged to the king of Hungary, Louis of Anjou. Later, the lake was transformed into a fishery but over time, the lake became one of the most beautiful places of leisure in the city and the most beautiful in the neighborhood. Today, the Gheorgheni neighborhood is a very beautiful, green, airy, and highly sought-after residential area for home purchase, housing the largest shopping center in Cluj-Napoca, near the lake.

Here, the inhabitants can enjoy numerous services, being located relatively at short distances, such as public transport stations, university headquarters, cinemas, parks, etc. Currently, about 45,000 people live in this neighborhood.

Table 2:

Results of the case study on the Gheorgheni neighborhood

\begin{tabular}{|l|l|l|}
\hline & Distance (in minutes) & Distance on foot (in km or m) \\
\hline Medical services & $1 \mathrm{~min}$ & $96 \mathrm{~m}$ \\
\hline Financial services, banks & $3 \mathrm{~min}$ & $220 \mathrm{~m}$ \\
\hline Public transport station & $2 \mathrm{~min}$ & $180 \mathrm{~m}$ \\
\hline University & $10 \mathrm{~min}$ & $850 \mathrm{~m}$ \\
\hline Schools & $4 \mathrm{~min}$ & $350 \mathrm{~m}$ \\
\hline Kindergarten & $5 \mathrm{~min}$ & $350 \mathrm{~m}$ \\
\hline Shopping center & $3 \mathrm{~min}$ & $220 \mathrm{~m}$ \\
\hline Park & $2 \mathrm{~min}$ & $200 \mathrm{~m}$ \\
\hline $\begin{array}{l}\text { Entertainment (cinema, } \\
\text { theatre, opera) }\end{array}$ & $12 \mathrm{~min}$ & $1.0 \mathrm{~km}$ \\
\hline Car parking & $11 \mathrm{~min}$ & $850 \mathrm{~m}$ \\
\hline $\begin{array}{l}\text { Free time/ Socializing } \\
\text { (restaurant, bar, coffee Shop) }\end{array}$ & $6 \mathrm{~min}$ & $500 \mathrm{~m}$ \\
\hline $\begin{array}{l}\text { Beauty services (barber shop, } \\
\text { hair salon, nails salon) }\end{array}$ & $3 \mathrm{~min}$ & $210 \mathrm{~m}$ \\
\hline $\begin{array}{l}\text { Accommodation services } \\
\text { Hotel/Guest house }\end{array}$ & $7 \mathrm{~min}$ & $550 \mathrm{~m}$ \\
\hline \begin{tabular}{l} 
Church \\
\hline
\end{tabular} & $1 \mathrm{~min}$ & $69 \mathrm{~m}$ \\
\hline
\end{tabular}

Source: Own compilation

In contrast to the Bulgaria neighborhood, the residents who live in the Gheorgheni neighborhood had to choose the car instead of walking only for a few services. For activities like taking children to school, shopping, paying bills, and so on, they can walk, as all of these services are at a maximum walking distance of 5 minutes. 
c) Downtown - City Center

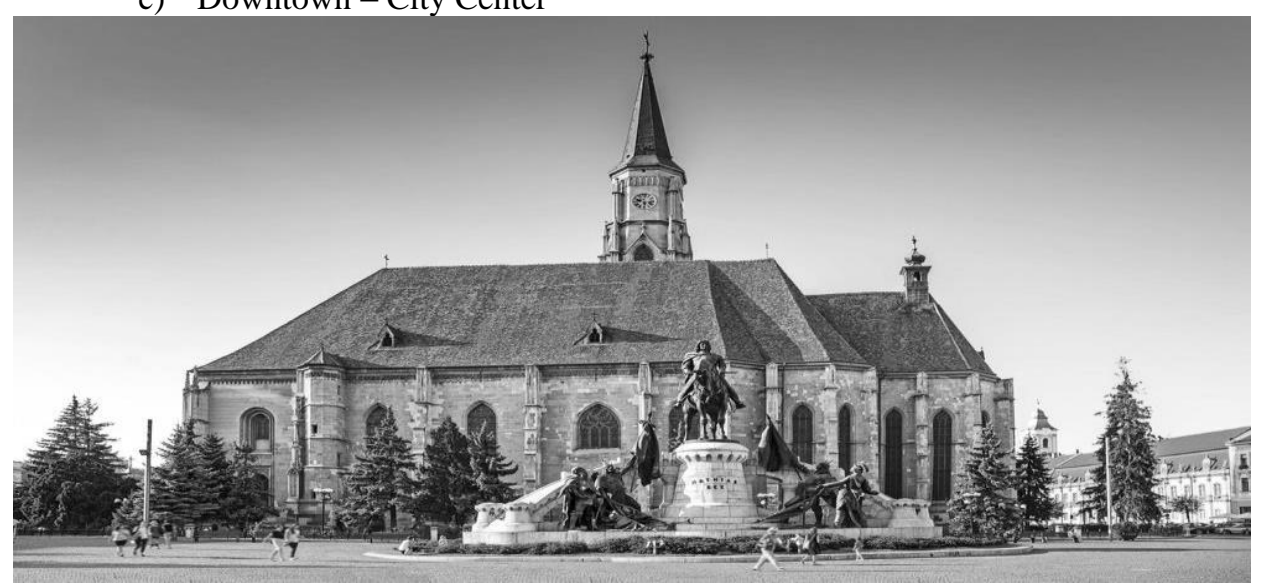

Figure 4: City Centre

Source: Own photo

The main central area is the cultural, financial, administrative and commercial area of ClujNapoca. It is structured in 4 large squares that form a triangle: Unirii Square, Mihai Viteazul Square and Avram Iancu Square (where the Romanian Opera and the Orthodox Cathedral are located). The center is individualized compared to the rest of the city after a series of monumental and historical architectural buildings, dating from the XVII-XX centuries. The zero point in the city of Cluj-Napoca is Unirii Square, which is the "medieval nucleus of the city", grouped around the Catholic Cathedral of St. Michael and the Statue of Matei Corvin. The walls of the medieval fortress delimit the former historical fortress of the city that once had only 45 ha. Unirii Square is the largest market $(220 \mathrm{~m}$ x $160 \mathrm{~m})$ in the countries of Eastern and SouthEastern Europe. In the first part of the 20th century, the square was named Regele Matei Square, after Matei Corvin. After 1980, the square was called Unirii Square, a name that is still preserved today. Colloquial is also called the Great Square or simply the Center. Unirii Square also houses other famous buildings such as: on the side is the Bánffy Palace, which now houses the Art Museum and the two buildings built in the mirror, from which Iuliu Maniu Street begins. On the southern side are the former City Hall and the National Bank. In the southwest corner, you can see the Continental Hotel Building, built in 1894. In addition to the historical, architectural, cultural, administrative, financial and commercial role that it successfully fulfills, the central area also plays a residential role, in a smaller measure. Most of the buildings in which this residential function is found are in the buildings with the minimum height of the ground floor and one floor/attic, where on the ground floor there is an ongoing commercial activity/services and upstairs are in most cases, the home of the business owner. It is very convenient for a buyer to opt for a home in the central area, even small, because absolutely any kind of services, institutions, promenades, shopping, hospitals are in the central area, so it is no longer necessary to travel in other places of the city, except the airport which is located at the exit of the city. Currently, about 38,000 people live in the central area. 
Table 3:

Results of the case study on City Center

\begin{tabular}{|l|l|l|}
\hline & Distance (in minutes) & Distance on foot (in $\mathrm{km}$ or m) \\
\hline Medical services & $2 \mathrm{~min}$ & $190 \mathrm{~m}$ \\
\hline Financial services, banks & $1 \mathrm{~min}$ & $34 \mathrm{~m}$ \\
\hline Public transport station & $2 \mathrm{~min}$ & $150 \mathrm{~m}$ \\
\hline University & $4 \mathrm{~min}$ & $270 \mathrm{~m}$ \\
\hline Schools & $5 \mathrm{~min}$ & $400 \mathrm{~m}$ \\
\hline Kindergarten & $7 \mathrm{~min}$ & $550 \mathrm{~m}$ \\
\hline Shopping center & $5 \mathrm{~min}$ & $350 \mathrm{~m}$ \\
\hline Park & $4 \mathrm{~min}$ & $350 \mathrm{~m}$ \\
\hline $\begin{array}{l}\text { Entertainment (cinema, } \\
\text { theatre, opera) }\end{array}$ & $8 \mathrm{~min}$ & $650 \mathrm{~m}$ \\
\hline Car parking & $1 \mathrm{~min}$ & $84 \mathrm{~m}$ \\
\hline $\begin{array}{l}\text { Free time/ Socializing } \\
\text { (restaurant, bar, coffee shop) }\end{array}$ & $1 \mathrm{~min}$ & $64 \mathrm{~m}$ \\
\hline $\begin{array}{l}\text { Beauty services (barber shop, } \\
\text { hair salon, nails salon) }\end{array}$ & $3 \mathrm{~min}$ & $220 \mathrm{~m}$ \\
\hline $\begin{array}{l}\text { Accommodation services } \\
\text { Hotel/Guest house }\end{array}$ & $3 \mathrm{~min}$ & $210 \mathrm{~m}$ \\
\hline Church & $1 \mathrm{~min}$ & $40 \mathrm{~m}$ \\
\hline
\end{tabular}

Source: Own compilation

In contrast with the other two neighborhoods, the Downtown area provides a full range of services and the longest distance that a citizen has to walk is about $650 \mathrm{~m}$, which means 8 minutes.

In the Downtown area, the citizen may find all required services and facilities.

In the central area there are enough parking spaces, whether they are concentrated in the form of a parking lot (multi-level) or they are along the streets, they are used for a fee. Residents of the entire city can benefit from a place or a maximum of two parking spaces in the vicinity of the house, in the form of a monthly subscription that is paid to the local administration. Also, depending on the area where the person lives or where the parking place is located, there are different fees about the proximity to the central area - the closer the parking place is to the central area, the higher the fee. Fortunately, no building project is approved by the local administration that does not benefit from an underground car park containing at least one parking space per apartment and including parking spaces for visitors. As a result, the parking spaces in the central area are used predominantly by visitors/people working in that area for a certain period.

\section{Conclusions}

After analyzing the three areas - the Bulgaria neighborhood, Gheorgheni neighborhood and Downtown - we can draw the following conclusions:

- In the central area, the services are numerous, diversified and people can easily move by public transport from any point in the city to the services/facilities objectives located in the city center. They can complete their tasks efficiently, as these services are at maximum 5 minutes away from each other, then they are able to return home using again the public transport. They can also use their own car that may be left in a parking space in the central area and then use it again to return home. This is only required if they do not live in the central area; residents of downtown can access goods and services on foot. 
- in the Gheorgheni neighborhood, the services are also numerous, though less diversified than in the central area. Basic services exist and the citizens can solve most of their daily or weekly tasks without having to use their car due to the services being located at maximum 5 minutes away from their homes.

- in terms of services, the Bulgaria neighborhood ranks the worst, lacking services and facilities, which forces residents to walk distances of more than one kilometer or even drive their car or use public transport in order to solve their daily tasks

This study can conclude that urban neighborhood design in City of Cluj-Napoca is still lacking in encouraging people to walk. In addition, certain community facilities that are provided in urban neighborhood areas are not provided at strategic locations. The sustainable principle can be adapted in designing a neighborhood to improve the walkability of people in the urban neighborhood area.

A further conclusion is that the Perry walking distance standard $(400 \mathrm{~m})$ is very suitable to be used in a city like Cluj-Napoca.

\section{Solution}

The local administration should offer fiscal incentives to investors who want to develop a business, a kindergarten, or a shopping center in those areas where they are missing and are absolutely necessary.

By adopting the "5-minute-walk distance" concept the local public administration and the architects and urban planners who are in charge of horizontal city planning could elaborate future urbanization plans that will allow citizens to walk to required services/facilities, to drive their cars less, and if they need to walk more than 5 to 10 minutes, to choose public transportation; these steps will benefit themselves and the entire city.

\section{References}

ABLEY, S. (2005): Walkability Scoping Paper, vol. 1, (10 pages), New Zealand Conference, title - Predicting Walkability

BANERJEE, T. AND W. C. BAER. (1984): Beyond the Neighborhood Unit: Residential Environments and Public Policy. New York: Plenum Press.

COUCH, C. (2016): Urban Planning. An introduction. Publisher: Red Globe Press, Macmillan

International Higher Education

https://morphocode.com/the-5-minute-walk/ (last access Month April 2020)

https://urbanlands.co/2010/08/23/the-five-minute-walk-more-than-just-a-circle/ (last access

Month April 2020)

https://www.conservapedia.com/index.php?title=Clarence_Perry (last access April 2020)

DIYANAH, I.A., HAFAZAH, A.K. (2012): Implications of Walkability towards Promoting Sustainable Urban Neighborhood, Thailand, Bangkok Conference on EnvironmentBehaviour Studies, Publisher: Elsevier Ltd. Selec, (10 pages)

FILIP, S. (2009): Planning Urban, Publisher: Presa Universitară Clujeană

LYNCH, K. (2004): Rural-Urban Interaction in the Developing World (6 pages) www.researchgate.net

MOSKOWITZ P.E. (2018): How to Kill a City: Gentrification, Inequality, and the Fight for the Neighborhood, Publisher: Bold Type Books

SPECK, J. (2013): Walkable City: How Downtown Can Save America, One Step at a Time, Publisher: North Point Press 
SHARIFI, A. (2013): Sustainiability at the Neighborhood Level: Assessment Tools and the Pursuit of Sustainability. Nagoya University, Department of Environmental Engineering and Architecture, (260 pages), www.researchgate.net

YONG, Y. AND DIEZ-ROUX, A.V. (2012): Walking Distance by Trip Purpose and Population Subgroup, Journal: American Journal of Preventive Medicine, vol. 43, (8 pages) 